J. Perinat. Med. $16(1988) 339$

\title{
Microcomputer-aided instruction for ob-gyn education
}

\author{
Frederick R. Jelovsek
}

Department of Obstetrics and Gynecology, University of Arkansas for Medical Sciences, Little Rock, AR, USA

\section{Introduction}

Health science computer-aided instruction (CAI) has a twenty year history, but a conspicuous lack of spread among teaching institutions as rapidly as advocates had originally predicted. Until recently, one had to be a computer programmer to develop an instructional module. Major hardware costs were a barrier to widespread use even after software was available. Many descriptions of CAI modules and their acceptance by students and teachers have been reported in the literature, however, the number of critical evaluative studies of their learning benefit have been much fewer. Those studies that have looked at CAI effectiveness have shown consistent findings. One such report of 59 evaluative studies of CAI [1] concluded that CAI provides small, but significant improvement in achievement and that the time needed for instruction was reduced by $33 \%$.

Among descriptive CAI studies, there are almost unanimous reports that students view this form of educational approach as positive and useful. Studies on student attitude show definite advantages on bipolar scales such as interesting-boring, fairunfair, and helpful-not helpful [2]. Although student satisfaction and increased learning are not necessarily conjoined, implementation of a new educational approach is facilitated by student acceptance.

Microcomputer software has been developed and is currently available which allows authors to create learning modules without having to learn a programming language. An hour of instructional time can still take over 100 hours to write and edit using these authoring systems. While less than the

\section{Curriculum vitae}

FREDERICK R. JELOVSEK MD, MS is a native of Waukegan, Illinois, USA and received his undergraduate training at Johns Hopkins University in Baltimore, Maryland and medical school at the University of Michigan in Ann Arbor, Michigan. He took a residency in Obstetrics and Gynecology at the Uni-

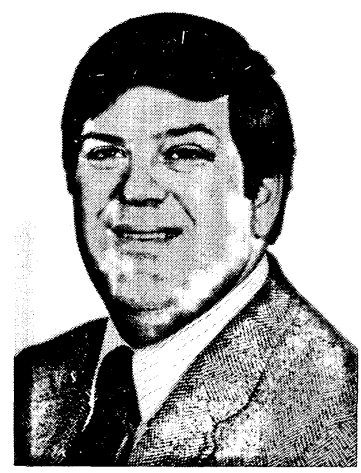
versity Hospital in Ann Arbor and then joined the $\mathrm{Ob}$ Gyn faculty at Duke University Medical Center in Durham, North Carolina in 1975. In 1984, Dr. Jelovsek moved to Little Rock, Arkansas where he is currently in associate professor in the Department of Obstetrics and Gynecology at the University of Arkansas for Medical Sciences. Computer applications in medicine have been a major area of interest and research for Dr. Jelovsek and he is currently chairman of the Task Force on Computers for the American College of Obstetricians and Gynecologists and he is president of the American Association for Medical Systems and Informatics, an 800 member professional society dedicated to the field of medical information science and systems.

$300-500$ hours required when programming from scratch, it remains a barrier for most medical school instructors. Authoring software does not use an input format which facilitates conversion of existing, written materials, and while this major time commitment to develop CAI may be satisfactory for commercially distributed programs, it is unacceptable to most instructors who must frequently change their materials due to changes in 
medical knowledge or changes in assigned teaching responsibilities. To address this need for CAI material which can be quickly created and easily modified, PC-CAI software has been developed for the PC-DOS/MS-DOS, IBM compatible microcomputers.

\section{Methods}

PC-CAI (version 2.0) is written in Microsoft C, compiled and uses assembly language subroutines to improve speed of performance. It requires $256 \mathrm{~K}$ memory and can be run from either floppy disk drives or a hard disk.

The software is basically a text driver of wordprocessed files that have been organized according to simple rules. Delimiters between blocks of text and delimiters separating parameters within control lines, are used to define and control display, branching, scoring, feedback statements, explanations, references, menu creation and types of questions. In addition to the basic multiple choice response, question types include: multiple response-at-a-screen (to simulate patient management, erasure-type questions), text matching, text matching using soundex (for those difficult to spell syndrome names), fill-in-the-blank, (to gather data or survey responses), non-ASCII keyboard read (for software tutorials), module branching, and statements (informational, display page only, no choice expected).

Delimiters, such as “\$”, “\#”, “!”, “@”, “comma”, and "space" separate parameters withiin control lines, and between blocks of text so that PC-CAI knows how to control the display, branching, scoring, feedback statements, explanations, references, menu creation and types of questions. Each wordprocessed text file (record file) is composed of up to 15 presentation pages. Each page contains all of the information associated with a primary VDT screen of text, ie. all possible responses, feedbacks to those responses, explanation and references. The pages are separated by a " $\$$ " as the first character in a line. Each presentation page has up to four subrecords separated by a "\#" sign as the first character on a line:

1) Main screen control line and text,

2) Response with feedback subrecord,

3) Explain text subrecord,

4) References text subrecord
For example, one page of a file might look like table I.

\section{Results}

PC-CAI has been developed and tested over the past 3 years. Student test questions based upon our faculty lectures are used for the third-year clinical clerkship. None of the core faculty lectures are replaced by the CAI modules, but rather the teaching tools are used to expand lecture topics and to be used while they are on a specific clinical rotation (table II). Lectures are given once to all students rotating through the service and since not all students are in the specific clinical area (obstetrics, gynecology, outpatient clinics, oncology) at the time a lecture is given, the CAI modules serve to reinforce material to be learned at a more pertinent time. This form of learning has been well received by the students, however we were unable to measure a performance difference when the modules were made voluntary. There were no differences in a average scores for a national exam taken at the end of school year 1986-87 for students who had modules available during their rotation, versus students on alternate rotations, who did not have CAI modules available for voluntary use. We are currently conducting a prospective trial of voluntary versus mandatory use.

Practice test questions for $\mathrm{Ob}-\mathrm{Gyn}$ residents have been used in their preparation for the annual intraining written examination. Computer tracking of responses on practice questions is used to construct resident-specific study plans in the six weeks prior to this national test. We have found that residents can improve their relative performance in counselled, "weak" subjects versus uncounselled, strong subjects. We also have found that there is a major Hawthorne effect such that all subjects showed national rank improvement.

Time required to convert written material into a computer-aided-instruction format has been greatly reduced using PC-CAI. Since significant effort is spent adjusting the visual and logistical format of instruction material, using one's favorite word processor in conjunction with a few formatting rules, decreases learning time to author a module. The first computer program that most faculty master is word processing; many microcomputer word processing programs outperform their counterparts on mini- and mainframe computers. This is especially true of documents where 
Table I. Example of part of a word-processed file that is driven by PC-CAI. This represents one of up to 15 possible "pages" per file, ie text and control associated with one display screen.

1,Q,D,72,Antepartum, Preterm Labor

1. Which of the following is TRUE about patients who are at risk for preterm labor:

A. Effacement of the cervix is not a risk factor.

B. Hypertension is correlated with signs of cervical ripening

C. Early vaginal bleeding is unrelated to preterm labor.

D. Routine antepartum vaginal exams for cervical effacement may help predict preterm labor.

E. Uterine contractions noticed by the patient are not predictive of preterm labor.

\section{\#}

$1,0,1$

Incorrect - Effective uterine contractions pull the lower uterine segment around the presenting part while at the same time the fetus is being pushed lower into the birth canal. Thus, thinning of the cervix occurs (effacement).

!

$2,0,1$

Incorrect - High maternal blood pressure has been found to have no relationship to early cervical changes in preterm labor. !

$3,0,1$

Incorrect - Early vaginal bleeding, especially in the second trimester, is an important predictor that preterm labor is likely to occur.

\section{$4,1,2$}

Correct - Early detection of cervical changes (shortening of the cervix, dilatation of the internal os, and effacement) are predictors of preterm labor, which could be evaluated by periodic vaginal exams.

!

$5,0,1$

Incorrect - Increased uterine contractions are dangerous signs that a preterm labor has begun.

\#

There is a similar maturation process of the cervix in preterm labor to that of term labor. The only difference being that maturation occurs weeks earlier in preterm births. Thus, early detection of cervical changes by vaginal examination should allow some forecast for preterm labor. These cervical changes include: (effacement) expansion of the lower uterine segment, short cervix with dilatation of the internal os, increased uterine contractions, and early vaginal bleeding.

\section{\#}

Papiernik E, Bouyer J, Collin D, Winisdoerffer G, and

Dreyfus J: Precocious Cervical Ripening and Preterm Labor. Obstet Gynecol 67: 238, 1986.

$\$$

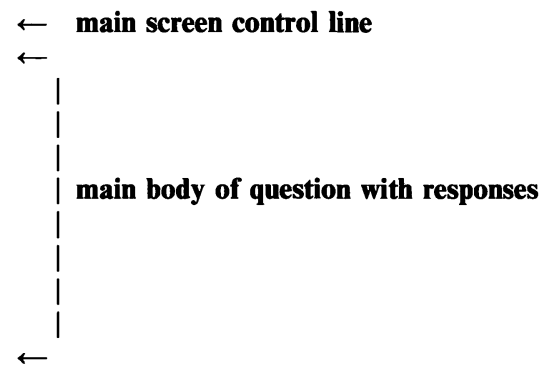

$\leftarrow$ control line for feedback to response 1

$\leftarrow \quad$ test for feedback 1

1

$\leftarrow$ control line for feedback to response 2

$\leftarrow$ text for feedback 2

$\leftarrow$ control line for feedback to response 3 text for feedback 3

control line for feedback to response 4

| text for feedback 4

$\leftarrow$

$\leftarrow$

control line for feedback to response 5 text for feedback 5

$\longleftarrow$

$\leftarrow$

text for general explanation to entire question

$\leftarrow$ references (text) pertinent to entire

$\leftarrow$ question 
Table II. Example of the computer screen, main menu for third-year student CAI programs.

Department of Obstetrics and Gynecology

University of Arkansas for Medical Sciences

3rd Year Clerkship Lecture Questions for Study

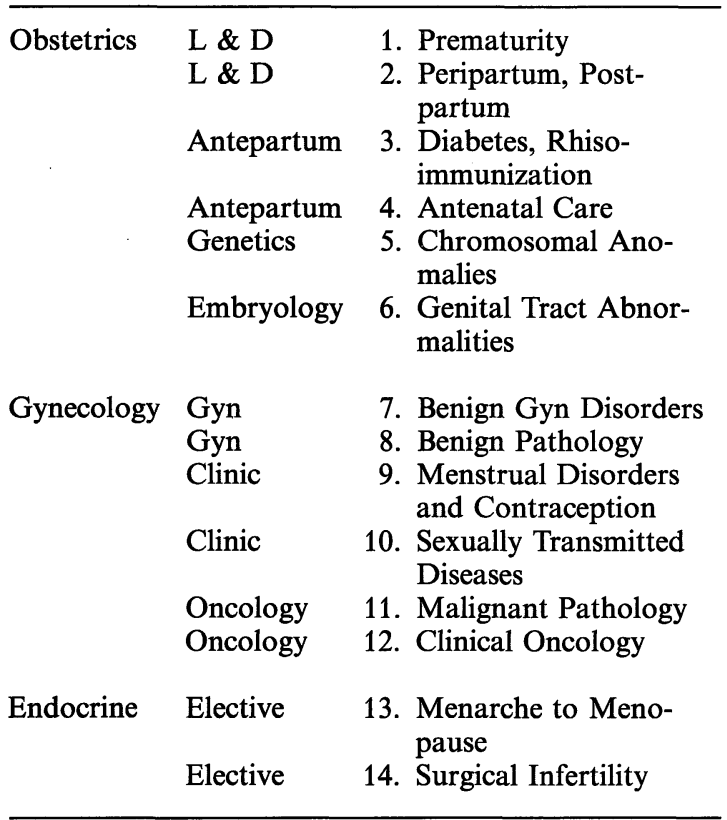

Enter a \# choice, or $\mathrm{X}$ to exit and then hit $\leftarrow$ (the ENTER or RETURN key)

cut-and-paste and paragraph reformatting are the most frequently used functions and where screen output is routed directly to screen memory and not through the operating system. Once test questions or didactic frames are typed into a wordprocessed file without any special formatting, the time necessary to add the extra formatting for that file to be "driven" by PC-CAI varies from about 3 minutes per 10 questions, where the only feedback is "correct" or "incorrect", to 20 minutes per 10 questions when there is extensive feedback text for all possible responses, overall question explanations, and included references.

The use of text only screens by CAI does limit the creativity of the author and visual satisfaction for the student, however, the availability of equipment around a medical center that can be used by the students is greatly increased, since the programs are not confined to a specific graphics board/ monitor configuration.

\section{Discussion}

In spite of recent price decreases for hardware and software, cost still prevents diffusion of the computer as an instructional tool. Most people who are inactive in this field do not appreciate how equipment expense and the lack of easy-to-use, affordable authoring packages are still barriers to creating and using CAI. One or two microcomputers cannot serve the CAI needs for a class of 100 medical students or even 16 residents. A classroom of twenty educational computer units is rarely convenient for medical students in the third or fourth year of training on various clinical rotations. Color graphics is important but there is still a $\$ 200$ premium for medium resolution and a $\$ 600-700$ premium for high resolution color graphics. The major diffusion barrier, however, is the inability to afford the least expensive monochrome unit at all locations where student learning is expected to occur.

A less obvious reason for lack of CAI use, albeit probably more important, is the inability to alter the few statements, questions or explanations with which a teacher disagrees. The $5 \%$ of teaching material perceived as wrong by an instructor, keeps a "not-invented-here" module from being recommended or assigned for use by learners. If an instructor could be given permission (and it was technically easy) to minimally change the content of a CAI module, there would likely be a greater use of this technology. Since it is not probable that copyright laws will change in the near future, the only mechanism by which this is likely to take place is for authors to market generic CAI modules. A license to permit alteration of the text for educational purposes should be included with the software.

This is not the first study to find significant advantages in an instructional architecture which uses simple, word-processed file format. HAUSE [3] found this to be true and it enabled his group to rapidly author modules in a relatively short period of time, for use on a variety of equipment. He found that there was an improved student cognitive performance in the basic medical sciences. More importantly, the variance in student performance decreased significantly using CAI modules, ie the weaker students improved their performance to a greater degree than did stronger students. The classes more often approached complete mastery of the material. This seems very desirable for the learner at a medical student level. 


\section{Conclusion}

In spite of price/performance technology decreases over the last two decades, there remain significant barriers to using computers for medical student and physician-in-training instruction and testing. The exact role CAI should play in the education of medical students and residents in obstetrics and gynecology also remains to be further defined.
Teaching material will need to be shared among institutions if we are to collate a comprehensive set of CAI materials. Where CAI has been used, it has worked and been well received by students. This study has confirmed the usefulness for authoring software that allows faculty to quickly create, and easily modify, computer-aided educational packages that complement their teaching methods, habits and resources.

\begin{abstract}
PC-CAI is a computer program that presents text characters from a word-processed file. The software was created to allow rapid authoring of computer-aidedinstruction modules or multiple choice tests that give explanation and feedback to the student about their choice of responses. The program is IBM-PC/XT/AT compatible under MS-DOS. It is used in the Department of Obstetrics and Gynecology for medical students to supplement faculty lectures and also to administer preand post-tests to those students. The program is addi-
\end{abstract}

tionally used to create practice tests for our residents to prepare for their in-training exams. The software's main forte is to create multiple choice question modules, with feedback and explanations, that serve as learning tools rather than just as testing tools. Its use has enabled our department to create a comprehensive set of teaching modules in a relatively short period of time. These modules are easily modifiable as medical concepts or teacher emphasis changes.

Keywords: Computer assisted instruction, education, medical, education, medical continuing, education, medical graduate, education, medical undergraduate, health education, learning, medical informatics.

\title{
Zusammenfassung
}

\section{Mikrocomputergestützte Schulung in der gynäkologisch- geburtshilfichen Ausbildung}

Es wird die Entwicklung und Anwendung eines Microcomputerprogramms für IBM PCs und Kompatible beschrieben. Die Software, PC-CAI, wurde so erstellt, daß die Ausbilder schnell computergestützte Lehrmodule für Studenten der Gynäkologie und Geburtshilfe und Ärzte erstellen können. Diese Module basieren auf dem Prinzip des Multiple Coice Tests mit erweitertem Feedback, Erklärungen, Verweisungen und Verzweigungsmöglichkeiten. Da das Programm auf Textdateien aufbaut, können sich die Ausbilder des vorhandenen Materials bedienen und Instruktionen per Computer in erheblicher kürzerer Zeit schaffen, als es der Gebrauch der hochentwickelten, wenn auch zeitsparenden, Ausbildungspakete zuließe.

Diese Software wurde umfassend an der Medizinischen Fakultät der Universität Arkansas in der Abteilung für Gynäkologie und Geburtshilfe geprüft. Praxisbezogene Testfragen bereiten die Ärzte auf ihr jährliches schriftliches Weiterbildungsexamen vor. Dies ermöglicht die Erstellung von angepaßten Studienplänen für Ärzte in- nerhalb des ausgewogenen Trainingsprogramms. Begleitend zur klinischen Rotation werden die Studenten Vorund Nachtests und, während sie spezielle Fachbereiche wie Geburtshilfe, Gynäkologie, Onkologie und die Poliklinik durchlaufen, ergänzende computergestützte Lernhilfen angeboten.

Der medizinischen Literatur kann man entnehmen, daß Computer-Lehrprogramme (CAI) die Varianz studentischer Leistungen vermindern können, d.h. daß schwächere Studenten den Lernstoff häufig nahezu völlig beherrschen, während die guten Studenten sich nicht so weitgehend verbessern. Es bleiben signifikante Barrieren zwischen dem Gebrauch von CAI Material; das größte Hindernis ist der Mangel an weitreichendem, fachspezifischem Stoff. Die Anwendung von PC-CAI würde den Autoren eine gegenseitige Nutzung des Materials ermöglichen. Der Autor dieses Artikels meint, daß innerhalb der Gynäkologie und Geburtshilfe die Erstellung von computergestützten Grundmodulen die Anwendung dieser Art zu lernen erleichtern würde.

Schlüsselwörter: Computergestützter Unterricht, Gesundheitserziehung, Graduierten-Ausbildung, Lernen, medizinische Ausbildung, medizinische Ausbildung von Studenten, medizinische Informatik, medizinische Weiterbildung. 


\section{Résumé}

Instruction aidée par microordinateur pour l'éducation gynéco-obstétricale

On décrit le développement et l'utilisation d'un programme sur microordinateur, IBM PC et compatibles. Le software, PC-CAI, a été créé de telle sorte que des instructeurs peuvent rapidement réaliser des molules d'apprentissage assisté par ordinateur pour les étudiants en GYN/OBST et les résidents. Ces modules sont fondés sur le principe des questions à choix multiples avec feedback étendu, explications, références et capacités d'extension. Du fait que le programme affiche le déroulement des mots, les instructeurs peuvent prendre les matériaux existants et créer des instructions aidées par ordinateur en un temps beaucoup plus bref que cela ne serait possible s'ils avaient à utilisar les programmes les plus sophistiqués, quoique très coûteux en temps.

Ce Software a été largement testé à l'université d'Arkensas pour les sciences médicales, au département d'obstétrique et de gynécologie. Des questions tests d'excercice pour les résidents en GYN/OBST sont utilisées pour la préparation de leur examen écrit annuel. Cela permet la construction de plans d'études spécifiques pour chaque résident pour son programme global d'entrainement. Les étudiants reçoient des pré et post tests sur la rotation clinique et reçoivent également des modules d'instruction supplémentaire aidée par ordinateur pour étudier à leur guise le champs des sous-spécialités, telles que l'obstétrique, la gynécologie, l'oncologie et les soins ambulatoires.

Il a été établi dans la littérature médicale que l'enseignement assisté par ordinateur (EAO) peut diminuer la variance des performances estudiantines, c'est-à-dire que les étudiants les plus faibles utilisent le matériel à fond, tandis que les étudiants les plus forts ne font pas de même. Il persiste des barrières significatives à l'utilisation des matériels d'EAO; la barrière principale est le manque de grande étendue des matériels. L'utilisation du PCCAI permettrait aux auteurs de participer à l'élaboration des matériels. L'auteur suggère qu'au sein de l'obstétrique et de la gynécologie, la production de modules d'EAO "générique" faciliterait l'utilisation de ce mode d'apprentissage.

Mots-clés: Apprentissage, éducation médicale, enseignement assisté par ordinateur, formation médicale continue, informattique médicale, santé et éducation.

\section{References}

[1] Kulik JA, CL Kulik, PA CoHEN: Effectiveness of computer-based college teaching: a meta-analysis of findings. Review of Educational Research 4 (1980) 525

[2] HAMBY CS: The effects of computer-assisted instruction on attitude and achievement. In: LEVY AH, BT WiLliams (eds): Proceedings AAMSI Congress. AAMSI, Washington, DC 1986
[3] HAUSE LL: Effective computer aided instruction in biomedical science. In: ACKERMAN MJ (ed): Symposium on computer applications in medical care. IEEE, Washington, DC 1985

Frederick R. Jelovsek, M.D.

University of Arkansas Medical Sciences 4301 West Markham Slot \#518

Little Rock, AR 72205

USA 